1993

\title{
Decoding Right to Refuse Treatment Law
}

Michael L. Perlin

New York Law School, michael.perlin@nyls.edu

Follow this and additional works at: https://digitalcommons.nyls.edu/fac_articles_chapters

Part of the Health Law and Policy Commons, and the Law and Psychology Commons

\section{Recommended Citation}

Perlin, Michael L., "Decoding Right to Refuse Treatment Law" (1993). Articles \& Chapters. 1119.

https://digitalcommons.nyls.edu/fac_articles_chapters/1119

This Article is brought to you for free and open access by the Faculty Scholarship at DigitalCommons@NYLS. It has been accepted for inclusion in Articles \& Chapters by an authorized administrator of DigitalCommons@NYLS. 


\title{
Decoding Right to Refuse Treatment Law
}

\author{
Michael L. Perlin*
}

\section{Introduction ${ }^{1}$}

The question of the right to refuse antipsychotic medication remains the most important and volatile aspect of the legal regulation of mental health practice. ${ }^{2}$ The issues that are raised - the autonomy of institutionalized mentally disabled individuals to refuse the imposition of treatment that is designed (at least in part) to ameliorate their symptomatology, the degree to which individuals subjected to such drugging are in danger of developing irreversible neurological side effects, the evanescence of terms such as "informed consent" or "competency," the practical and administrative considerations of implementing such a right in an institutional setting, and the range of the philosophical questions raised ${ }^{3}$-mark the litigation that has led to the articulation of the right to refuse treatment as "a turning point in institutional psychiatry" and "the most controversial issue in forensic psychiatry today". issues raised by the right to refuse antipsychotic medication are the potential infringement of individuals' constitutional rights, including the First Amendment rights to privacy and mentation, the Sixth Amendment right to a fair trial, the Eighth Amendment right to freedom from cruel and unusual punishment, and the Fourteenth Amendment's due process guarantee. Given the multiplicity and gravity of the issues involved in these cases, their significance frequently transcends the narrow focus of a "mental disability law" case.

*Professor of Law, New York Law School, 57 Worth St., New York, NY 10013, U.8.A.

A version of this article will appear as a chapter in The Law and Mental Disability, forthcoming from The Michie Co., Charlottesville, vA.

The author wishes to thank Debbie Dorfman for her extraordinary research assistance and Susan Perepeluk for her excellent editing assistance.

'The text infra accompanying notes 2-14 is generally adapted from Perlin, The Rlght to Refuse Treatment in a Criminal Law Setting, in Forensic Psychiatry: A Comprehensive Textboox (R. Rosnet ed. 1992) (in press), manuscript at 1-3.

${ }^{2}$ See generally, Brooks, The Right to Refuse Antlpsychotic Medications: Law and Policy, 39 RuTOERs L. Rev. 339 (1987); Gelman, Mental Hospital Drugging: Atomistic and Structural Remedies, 32 CLEVBLAND ST. L. Rev. 221 (1983-4); Plotkin, Limiting the Therapeutic Orgy: Mental Patlents' Right to Refuse Treatment, 72 NORTHWESTERN U. L. Rev. 461 (1977).

${ }^{3}$ See generally, 2 M. L. Perlin, Mental Disability Law: Civil and Criminal (1989), Chapter 5, at 215-438.

'See generally, Rhoden, The Right to Refuse Psychotropic Drugs, 15 HaRv. Civ. RiakTs-Civ. Liberties L. Rev. 363, 365 (1980).

'See generally, Brant, Pennhurst, Romeo and Rogers: The Burger Court and Mental Health Law Reform Litigation, 4 J. LEG. MED. 323, 345 (1983). 
The conceptual, social, moral, legal, and medical difficulties inherent in the articulation of a coherent right to refuse treatment doctrine have been made even more complicated by the United States Supreme Court's reluctance to confront most of the underlying issues in cases arising in civil settings. ${ }^{6}$ As a result of the court's decision in Mills $v$. Rogers to "sidestep" the core constitutional questions ${ }^{7}$ and its concomitant articulation of the doctrine that a state is always free to grant more rights under its constitution than might be minimally mandated by the U.S. Supreme Court under the federal constitution, ${ }^{8}$ two parallel sets of cases have emerged.

In one, state courts have generally entered broad decrees in accordance with an "expanded due process" model, in which the right to refuse treatment has been read broadly and elaborately, generally interpreting procedural due process protections liberally on behalf of the complaining patient. These cases have frequently mandated premedication judicial hearings, and heavily relied on social science data focusing on the potential impact of drug side effects, especially tardive dyskinesia. ${ }^{9}$ In the other, federal courts have generally entered more narrow decrees in accordance with a "limited due process model." These provided narrower administrative review and rejected broad readings of the Fourteenth Amendment's substantive and procedural due process protections, relying less on social science data (which was frequently ignored or dismissed as part of an incomprehensible system allegedly beyond the courts' self-professed limited competency). ${ }^{10}$ Generally (but not always), the state cases involved civil patients; more frequently, the federal cases dealt with individuals originally institutionalized because of involvement in the criminal trial process. ${ }^{11}$

As this short overview should demonstrate, it is impossible to authoritatively articulate one doctrine to cover all right to refuse treatment litigation. It is also impossible to state such a doctrine even for cases that arise in a "criminal law setting," since the simplest "unpacking" of that category reveals that there are at least seven major subcategories to which the right to refuse could be applied: to cases involving (a) defendants awaiting incompetency to stand trial

\footnotetext{
'Mills v. Rogers, 457 U.S. 291 (1982). But compare, Washington v. Harper, 494 U.S. 210 (1990), and Riggins v. Nevada, 112 U.S. 1810 (1992), discussed in Perlin \& Dorfman, Sanism, Social Science, and the Development of Mental Disability Law Jurisprudence, 11 BEHAv. SCI. \& L. -(1992) (in press), manuscript at 38-42.
}

'2 M.L. PeRLIN, supra note 3, 85.33 at 309-12; Wexler, Seclusion and Restraint: Lessons for Law, Psychiatry and Psychology, 5 INT'L J. L. \& Psychiatry 285, 290 (1982).

${ }^{8}$ Mills, 457 U.S. at 300; see generally, Perlin, State Constitutions and Statutes as Sources of Rights for the Mentally Disabled: The Last Frontier? 20 LoY. L.A. L. REv. 1249 (1987).

${ }^{9}$ See e.g., Rivers v. Katz, 67 N.Y. 2d 485, 495 N.E.2d 337, 504 N.Y.S.2d 74 (1986); Riese v. St. Mary's Hospital \& Medical Center, 198 Cal.App.3d 1388, 243 Cal.Rptr. 2431 (1987), app\%. dismissed, 774 P.2d 698, 259 Cal.Rptr. 669 (1989); see generally, Perlin, Reading the Supreme Court's Tea Leaves: Predicting Judicial Behavior in Civil and Criminal Right to Refuse Treatment Cases, 12 AM. J. Forens. PsychIATRY 39 (1991).

${ }^{10}$ See generally, United States v. Charters, 863 F.2d 302 (4th Cir. 1988) (en banc) cert. denied, 110 S.Ct. 1317 (1990); Perlin, Are Courts Competent to Decide Competency Questions? Stripping the Facade from United States v. Charters, 38 U. KAN. L. REv. 957 (1990). On the significance of courts' refusal to seriously consider social science data in this context. see generally, Perlin \& Dorfman, supra note 6.

"See generally, Perlin, supra note 9. 
(IST) determinations, (b) defendants found "permanently" IST in accordance with the Supreme Court's decision in Jackson $v$. Indiana, ${ }^{12}$ (c) defendants otherwise awaiting trial in jails, (d) defendants seeking to proffer a not guilty by reason of insanity (NGRI) defense, (e) defendants who have been institutionalized following an NGRI finding, (f) convicted defendants in prison, and (g) capital defendants who state officials seek to medicate so as to make them competent to be executed. ${ }^{13}$ However, if each of these categories is considered briefly, it may better illuminate whether any strands of doctrinal coherency can be spelled out. ${ }^{14}$

Doctrinal analysis has been made even more difficult by the Supreme Court's recent decision in Riggins $v$. Nevada. ${ }^{15}$ There, the Court followed the "expanded due process" model in finding that defendant's due process rights to a fair trial (at which he had raised the insanity defense) were violated by the involuntary imposition of antipsychotic drugs, and requiring "an overriding justification and a determination of medical appropriateness" prior to such forcible medication. ${ }^{16}$ The majority's decision in Riggins is by no means an end to the debate surrounding the rights of the mentally disabled to refuse antipsychotic medication. On one hand, Justice Kennedy's concurring opinion would have banned the use of antipsychotic medication to make a defendant fit to stand trial "absent an extraordinary showing" on the state's part; ${ }^{17}$ on the other, Justice Thomas's dissent appears to reject the notion that a defendant such as Riggins (who had originally asked for medical assistance as a jail inmate because he was "hearing voices") could ever raise a refusal of medication claim within the criminal trial context. ${ }^{18}$

In order to understand the scope and breadth of this right, it is necessary to try to "decode" it. We must try to separate its component parts, examine its constitutional roots, determine the "spin" factors that will likely drive future decisions in areas in which there have not yet been significant litigation, ${ }^{19}$ and try to determine whether "doctrinal coherence" can ever be achieved in this area.

This article will proceed in the following way. In the "State and Federal Systems" section, I discuss the lack of consistency within the state and federal judiciary system in dealing with these cases. In "Other Settings and Different Populations," I discuss the application of the right to refuse medication in other settings for different population, such as jails, community facilities, and state schools for retarded persons. In "Decoding the Right to Refuse Treat-

\footnotetext{
${ }^{12} 406$ U.S. 715 (1972).

${ }^{13}$ Beyond the scope of this article are yet other categories such as convicted defendants who are placed on probation or parole if they agree to comply with medication orders, and defendants found guilty but mentally ill (GBMI).

${ }^{14} C f$. Perlin, The Supreme Court, Mentally Disabled Criminal Defendant, and Symbolic Values: Random Decisions, Hidden Rationales, or "Doctrinal Abyss"? 29 ARIz. L. REv. 1 (1987).

${ }^{15} 112$ U.S. 1810 (1992).

${ }^{16} I d$. at 1815.

${ }^{17}$ Id. at 1817 (Kennedy, J., concurring).

${ }^{18}$ Id. at 1822-26 (Thomas, J., dissenting).

${ }^{19}$ See generally, Perlin, supra note 9.
} 
ment," I consider some of the reasons why courts decide right to refuse treatment cases the way they do, looking at the use of cognitive simplifying devices such as "heuristics," the impact of "sanism" on judicial decision-making, and the danger of "pretextuality" in the decision of such cases; I also stress the importance of "therapeutic jurisprudence" as an interpretive tool in considering right to refuse treatment law. ${ }^{20}$ I will also consider the potential future impact of the Riggins case in this area. ${ }^{21}$ Finally, I offer some final "decoding" suggestions.

\section{State and Federal Systems ${ }^{22}$}

It is important to begin this inquiry in the context of the particular time in legal history that institutional right to refuse litigation began. The timing of the emergence of this case law and public scrutiny in the late 1970s was no coincidence. The strategic impetus for this litigation flowed from decisions earlier in the decade on behalf of institutionalized individuals that had repudiated the "hands off" doctrine ${ }^{23}$ in a wide variety of cases broadening the applicability of both procedural and substantive due process protections to institutionalized individuals. ${ }^{24}$ While this litigation first arose in the state prison and jail settings, ${ }^{25}$ lawyers representing the mentally disabled - a classically "hidden" and disenfranchised group ${ }^{26}$ - began to turn to the federal courts in an effort to seek vindication of fundamental constitutional and civil rights, ${ }^{27}$ at first primarily in cases involving the right to treatment ${ }^{28}$ In the first rush of cases-arising from fact settings involving shocking disclosures of patient brutality, mistreatment, and abuse ${ }^{29}$ - federal judges openly embraced an activ-

\footnotetext{
${ }^{20}$ See e.g., Therapeutic Jurisprudence: The LAW As A Therapeutic Agent (D. Wexler \& B. Winick eds. 1991).

${ }^{21}$ See Perlin, Riggins v. Nevada: Forced Medication Collides With the Right to a Fair Trial, 16 NEWSLETTER AM. ACAD. Psychiatry \& L. - (Dec. 1992) (in print).

${ }^{22}$ The text infra accompanying notes 23-60 is largely adapted from Perlin, supra note 9.

${ }^{23}$ See e.g., Banning v. Looney, 213 F. 2d 771 (10th Cir.), cert. denied, 348 U.S. 854 (1954); Siegel v. Ragan, 180 F. 2d 785, 788 (7th Cir. 1950). See generally, Note, Beyond the Ken of the Courts: A Critique of Judicial Refusal to Review the Complaints of Convicts, 72 YALE L. J. 506 (1963).

${ }^{24}$ See generally, Perlin, supra note 8, at 1249-52; 1 M.L. PeRLIN, supra note 3, 81.03, at 5-9.

${ }^{25}$ See generally, Alexander, The New Prison Administrators and the Court: New Directions in Prison Law, 56 TEX. L. REV. 963, 964-65 (1978).

${ }^{26}$ See e.g., City of Cleburne v. Cleburne Living Center, 473 U.S. 432, 461-62 (1985) (Marshall, J., concurring in part $\&$ dissenting in part) (mentally retarded individuals have been subject to "lengthy and tragic' history of segregation and discrimination that can only be called grotesque"). See generally, United States v. Carolene Products Co., 304 U.S. 144, 152 n. 4 (1938).

${ }^{27}$ M.L. PERLIN, supra note 3, $\$ 1.03$, at 8. The seminal article explaining the court's role in such litigation remains Chayes, The Role of the Judge in Public Law Litigation, 89 HARV. L. REV. 1281 (1976).

${ }^{28}$ See generally, 2 M. L. PerLIN, supra note 3, Chapter 4.

${ }^{29}$ See e.g., New York State Ass'n for Retarded Children, Inc. v. Rockefeller, 357 F. Supp. 752, 755-56 (E.D.N.Y. 1973); Wyatt v. Aderholt, 503 F. 2d 1305, 1311 n.6 (5th Cir. 1974):
}

One [Alabama state hospital patient] died after a garden hose had been inserted into his rectum for five minutes by a working patient who was cleaning him; one died when a fellow patient hosed him with scalding water; another died when soapy water was forced into his mouth; and a fourth from a self-administration of drugs which had been inadequately secured. 
ist model that "transfigured institutional care of the mentally ill in the nation." ${ }^{30}$

By the time the litigation largely shifted focus from the "right to treatment" to the "right to refuse treatment," some recession from this position was noticeable. ${ }^{31}$ Refusal of treatment litigation challenged the autonomy and authority of state hospital doctors to provide what had been considered as "standard" treatment: the administration of psychotropic medication to institutionalized, mentally ill patients ${ }^{32}$ - on the surface, a seeming-far cry from the type of "shock the conscience" physical brutality present in the prototypic right to treatment case of Wyatt v. Stickney. ${ }^{33}$ Thus, even in Rennie v. Klein, one of the broadest, most scholarly and most sensitive of the first generation of right to refuse treatment cases, Judge Stanley Brotman eloquently and candidly laid out the dilemma facing him: "A little knowledge can be dangerous, and this court is hesitant to diagnose mental illness and prescribe medication. ${ }^{334}$

Later, when the Third Circuit first modified Judge Brotman's decision in Rennie, it limited the substantive and procedural sweep of its protections, and recalibrated its reading of the "least restrictive alternative" construct. ${ }^{33}$ The Third Circuit warned carefully about overintrustion by the courts into the daily operation of mental institutions:

\footnotetext{
${ }^{30}$ Heller, Extension of Wyatt to Ohio Forensic Patients, in WyATt V. STICKNEY: RETrosPECT AND Prospect 161, 172 (L.R. Jones \& R. Parlour eds. 1981) (ReTrosPeCT).

${ }^{31}$ This recession did not affect the earliest right to refuse cases that had involved the forcible administration of drugs for purely punitive purposes. See e.g., Knecht v. Gillman, 488 F. 2d 1136, 1137-40 (8th Cir. 1973) (use of apomorphine as "aversive stimuli"); Mackey v. Procunier, 477 F. 2d 877-78 (9th Cir. 1973) (use of succinylcholine as aversive conditioning).
}

${ }^{32} \mathrm{On}$ the interplay between the administration of such medication and the historic roots of deinstitutionalization, see Perlin, Competency, Deinstitutionalization, and Homelessness: A Story of Marginalization, 29 Hous. L. REV. 63, 102-04 (1991).

${ }^{33} 325$ F. Supp. 781 (M.D. Ala. 1971), affd sub. nom. Wyatt v. Aderholt, 503 F. 2d 1305 (5th Cir. 1974); see also, Drake, The Development of Wyatt in the Courtroom, in RETROSPECT, supra note 29, at 36 (characterizing "horror" of pre-Wyatt institutions in Alabama). As the right to refuse litigation developed, it became clear that this dichotomy was frequently illusory. See e.g., Rennie, 476 F. Supp. at 1302 (hospital staff increased patient's medication as "reprisal" for his decision to contact an attorney).

${ }^{34}$ Rennie, 462 F. Supp. at 1140 . The question in Rennle, Judge Brotman found, tracked the question asked rhetorically by Judge Bazelon: "[H]ow real is the promise of individual autonomy for a confused person set adrift in a hostile world?" Id. at 1146, quoting Bazelon, Institutionalization, Deinstitutionalizatlon, and the Adversary Process. 75 CoLUM. L. REv. 897, 907 (1975).

${ }^{39}$ The Rennie trial court had extended the doctrine of the "least restrictive alternative" - regularly employed previously in mental health litigation to questions of custodial settings, see e.g., Welsch v. Likins, 373 F. Supp. 487, 501 (D. Minn. 1974)-to medication choices. See Rennie, 462 F. Supp. at 1146, quoting Winick, Psychotropic Medication and Competence to Stand Trial, 1977 AM. BAR. Found. REs. J. 769, 813 (patient "may challenge the forced administration of drugs on the basis that alternative treatment methods should be tried before a more intrusive technique like psychotropic medication is used").

The Supreme Court has never squarely confronted the application of the "least restrictive alternative" principle to such cases. Compare Youngberg v. Romeo, 457 U.S. 307, 324 (1982) (involuntarily committed mentally retarded individual has right to "reasonably nonrestrictive confinement conditions"). But see, Riggins v. Nevada, 112 S. Ct. 1810 (1992) (while no bright line test set out for medical appropriateness in context of insanity defense pleader's right to refuse during trial, due process requires a demonstration by the state that the treatment was medically appropriate and either (a) considering less intrusive alternatives, essential for the defendant's safety or the safety of others, or (b) considering less intrusive means, essential for an adjudication of guilt or innocence). 
This is not to say that the least intrusive means requires hourly or daily judicial oversight. Obviously that would be an unworkable standard. Rather, what is reviewable is whether the choice of a course of treatment strikes a proper balance between efficacy and intrusiveness. ${ }^{36}$

The Supreme Court, however, gave little guidance. In 1982, in Mills $v$. Rogers, ${ }^{37}$ a case that arose contemporaneously with Rennie, ${ }^{38}$ it sidestepped the constitutional issues by remanding the case to the First Circuit for consideration of the impact of an intervening Massachusetts state court decision. ${ }^{39}$ The Supreme Court then remanded Rennie $e^{40}$ in light of its contemporaneous decision in Youngberg $v$. Romeo, ${ }^{41}$ that had, in establishing a minimal right to training for institutionalized mentally retarded individuals, announced as its benchmark for assessing patients' rights claims the test of "substantial professional judgment." ${ }^{42}$ On remand (in Rennie II), a sharply divided Third Circuit reiterated most of its earlier holding that involuntarily committed patients do have a qualified right to refuse the administration of psychotropics, ${ }^{43}$ but, as part of its holding, relied on Youngberg in jettisoning the "least restrictive alternative" standard for drugging decisions. ${ }^{44}$

In the wake of Youngberg, Rogers, and Rennie II, the focus of litigation turned swiftly to state courts, and state constitutional law became an increasingly more important vehicle through which right to refuse claims were assessed. ${ }^{45}$ In Rivers $v$. $K a t z,{ }^{46}$ a paradigm state constitutional law case, the New York Court of Appeals concluded that state constitutions afforded involuntary patients a fundamental right to refuse, holding that neither mental illness nor institutionalization per se could stand as a justification for overriding such a right on either police power or parens patriae grounds. ${ }^{47}$ State cases such as

${ }^{36}$ Rennie, 653 F. 2d at 847. See also, e.g., Rogers, 634 F. 2d at 656-57 (in accord).

${ }^{37} 457$ U.S. 291 (1982).

${ }^{38} \mathrm{At}$ the trial level, the District Court had originally entered even a broader antidrugging injunction than had Judge Brotman done in Rennie. See Rogers v. Okin, 478 F. Supp. 1342 (D. Mass. 1979), mod., 634 F. 2d 650 (1st Cir. 1980), vacated and remanded sub. nom. Mills v. Rogers, 457 U.S. 291 (1982), on remand, 738 F. 2d 1 (1st Cir. 1984).

${ }^{39}$ Mills, 457 U.S. at 306, remanding in light of In Re Richard Roe III, 383 Mass. 415, 421 N.E. 2d 40, 5152 (1981) (holding that a noninstitutionalized incompetent patient had a right to a prior judicial hearing at which he could assert the desire to refuse antipsychotic drug treatment). See supra text accompanying note 7.

${ }^{40} 457$ U.S. 1119 (1982).

${ }^{41} 457$ U.S. 307 (1982).

${ }^{42} I d$, at 323 ("Liability may be imposed only when the decision by the professional is such a substantial departure from accepted professional judgment, practice, or standards as to demonstrate that the person responsible did not base the decision on such a judgment"). The Supreme Court's recent decision in Riggins v. Nevada, 112 S. Ct. 1810 (1992), may be read to be questioning the continuing vitality of this doctrine in right to refuse contexts. See supra note 35.

${ }^{43}$ Rennie, 720 F. 2 d at $269-70$.

${ }^{44} \mathrm{Id}$. at 270.

${ }^{45}$ See Perlin, supra note 8.

${ }^{46} 67$ N.Y. 2d 485, 495 N.E. 2d 337, 504 N.Y.S. 2d 74 (1986).

${ }^{47}$ See generally, 2 M.L. PERLIN, supra note 3, at \$85.42-5.43A. 
Rivers $^{48}$ rejected arguments that involuntarily committed patients were "presumptively incompetent" because of their institutionalization. ${ }^{49}$ Thus, in the case of a competent patient, the right "to determine what shall be done with [one's] body" must be honored "even though the recommended treatment may be beneficial or even necessary to preserve the patient's life."

Cases such as Rivers and the California state decision in Riese v. St. Mary's Hospital and Medical Center $r^{51}$ thus made it appear that the federal forum was, simply, a venue of the past for the adjudication of right to refuse treatment cases. ${ }^{52}$ Moreover, it appeared that the jurisprudential inquiries engaged in by the federal courts were simply irrelevant to state court judges. The Rivers opinion, for instance, was silent on the jurisdictional split that followed the Mills remand. ${ }^{53}$ It astonishingly did not even mention the opinion in Project Release v. Prevost, ${ }^{54}$ where the Second Circuit (the federal circuit that includes New York) had upheld the constitutionality (on federal constitutional grounds) $)^{s s}$ of the very regulation struck down on state constitutional grounds by the Rivers court.

Rivers ringingly endorsed a preadministration judicial hearing in right to refuse cases where the patient was not a present danger. This stands in sharp contrast to the methodology implicitly endorsed by the United States Supreme Court that apparently seemed to accept a more informal, medically focused model so as to adequately satisfy the demands of the due process clause of the federal constitution," that would employ the "substantial professional judgment" test as the benchmark of institutional treatment adequacy, ${ }^{57}$ and that

\footnotetext{
40ther similar cases are cited in id., 85.43A, at 33-34 n. 846.2 (1992 pocket part).

19The court reasoned that, without more, neither the fact of mental illness or commitment "constitutes a sufficient basis to conclude that [such patients] lack the mental capacity to comprehend the consequences of their decision to refuse medication that poses a significant risk to their physical well-being." Rivers, 504 N.Y.S. $2 \mathrm{~d}$ at 78,79 . On the ways that courts frequently subvert this doctrine in the trials of involuntary civil commitment and incompetency to stand trial cases, see Perlin, Pretexts and Mental Disability Law: $A$ Case of Competency, 47 U. MLAMI L. REV. - (1993) (in print).

${ }^{30} I d$. at 78. On the empirical impact of Rivers, see e.g., Zito, Haimowitz, Wanderling \& Mehta, One Year Under Rivers: Drug Refusal in a New York State Psychiatric Facility, 12 INTL J. L. \& PsYchIATRY 295 (1989); Cournos, McKinnon \& Adams, A Comparison of Clinical and Judicial Procedures for Reviewing Requests for Involuntary Medication in New York, 39 Hosp. \& CoMmUN. PsYCHIATRY 851 (1988).

s'209 Cal. App. 3d 1303, 243 Cal. Rptr. 241 (1987), appeal dismissed, 774 P. 2d 698, 259 Cal. Rptr. 609 (1989).

${ }^{32}$ See Perlin, supra note 8, at 1265 ("the use of state constitutions and state statutes in state courts may be the last frontier for the mentally disabled").

${ }^{33}$ See 2 M.L. PerLin, supra note 3, 85.46, at 364-66.

54722 F. $2 \mathrm{~d} 960$ (2d Cir. 1983).

${ }^{55} I d$. at 980-81. I discuss this anomaly in 2 M.L. PERLIN, supra note 3, \$5.43, at 347.

${ }^{56}$ See e.8., Youngberg, 457 U.S. at 322-23 ("[T]here certainly is no reason to think judges or juries are better qualified than appropriate professionals in making such decisions [about internal operations of state mental institutions]"); Roth, The Right to Refuse Psychiatric Treatment: Law and Medicine at the Interface, 35 EMORY L.J. 139, 157 (1986) ("while the 'right to refuse' is a fascinating issue for law and psychiatry, the problem remains clinical"). Compare Riggins, supra (discussed in this context in M. Perlin, "Law As a Therapeutic and Anti-Therapeutic Agent" (paper presented at University of Massachusetts' Medical Center's Department of Psychiatry's annual conference, May 1992, Auburn, MA), and in Perlin, supra note 21.

${ }^{57}$ See Youngberg, 457 U.S. at 323.
} 
would not constitutionally compel adherence to the "least restrictive alternative" in institutional drugging cases. ${ }^{58}$

The subsequent decision by the Fourth Circuit in Untied States $v$. Charters, severely limiting the rights of pretrial detainees to refuse medication and requiring only the most minimalist compliance with the Youngberg professional judgment test, appeared to augur the demise of the federal court as a forum for right to refuse cases. ${ }^{59}$ However, the Supreme Court's recent decision in Riggins $v$. Nevada may have served to resuscitate federal courts as the site for litigation in such cases. ${ }^{60}$

\section{Other Settings and Different Populations ${ }^{61}$}

Although the great bulk of right to refuse treatment litigation has involved institutionalized, mentally ill persons, more recent cases have also dealt with the application of the right in other facilities (e.g., jails, the community, state schools for retarded persons) and to cases involving special populations (e.g., persons found NGRI). While these cases are still relatively numerically few, ${ }^{62}$ they at least indicate that the scope of the problem extends beyond simple decision making involving civilly committed mental patients. Also, the fact that the Supreme Court recently addressed the question of the refusal of medication in the context of a fair trial question in Riggins $v$. Nevada $a^{63}$ should likely lead to greater attention paid to this area in the future.

\section{In Civil Settings}

In Facilities for Mentally Retarded Persons. The litigated constitutional ${ }^{\text {of }}$ cases dealing with the rights of residents of state schools for the retarded to refuse the administration of antipsychotic drugs have focused on the use of drugs as punishment within the larger context of right to treatment/institutional conditions litigation. ${ }^{65}$ Thus, in Welsch $v$. Likins, ${ }^{66}$ the district court

\footnotetext{
${ }^{38}$ In its resurrection of the "least restrictive alternative" standard, Rivers made no mention of the Youngberg decision.

${ }^{59}$ See Perlin, supra note 10, discussing United States v. Charters, 863 F. $2 \mathrm{~d} 302$ (4th Cir. 1988) (en banc), cert. den., 110 S. Ct. 1317 (1990). See infra Part III B 1.

${ }^{0}$ See supra notes 15-18; M. Perlin, supra note 56; Perlin \& Dorfman, supra note 6; Perlin, supra note 21.

${ }^{61}$ The text infre accompany notes $62-74$ is generally adapted from 2 M.L. PERLIN, supra note 3, $\$ \$ 5.61-$ 5.62, and id. (1992 pocket part).

${ }^{62}$ On the question of the application of the right to individuals in private hospitals, see Riese v. St. Mary's Hosp. \& Med. Center, 196 Cal. App. 3d 1388, 243 Cal. Rptr. 241 (1987), appeal dismissed, 259 Cal. Rptr. 669, 774 P. 2 d 698 (1988), discussed in 2 M.L. PERLIN, supre note 3, at 85.63.

On the question of the application of the right to voluntary patients, see Perlin, supra note 9, at 50.

${ }^{63} 112$ S. Ct. 1810 (1992).

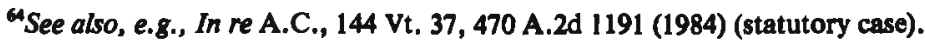

${ }^{65}$ See, e.g., Plotkin \& Gill, Invisible Manacles: Drugging Mentally Retarded People, 31 STAN. L. REv. 637, 674 (1979) (the "pervasive misuse of phenothiazines in most public institutions for mentally retarded persons is beyond question").
}

${ }^{66} 373$ F. Supp. 487 (D. Minn. 1974). See generally 2 M.L. PERLIN, supra note 3, at 84.19. 
found that the "excessive use of tranquilizing medication as a means of controlling behavior, not mainly as part of therapy, may . . . infringe on plaintiffs' rights under the Fourteenth Amendment and Eighth Amendment." And, in Wyatt $v$. Stickney, ${ }^{68}$ the district court's standards included elaborate procedures governing the use of such medication. ${ }^{69}$

In the Community. ${ }^{70}$ (a) Outpatient commitment. It is necessary to consider the interplay between the right to refuse treatment and outpatient commitment (OPC). ${ }^{71}$ Under OPC statutes, individuals in need of treatment "to prevent further disability or deterioration which would predictably result in dangerousness," who are "capable of surviving safely in the community," but are unable to make informed decisions "to seek voluntary treatment or comply with recommended treatment," are subject to commitment to community-based facilities. ${ }^{72}$ Statutes typically look at medication compliance as one of the criteria for involving $\mathrm{OPC},{ }^{73}$ and much of the relevant case law seems to explicitly endorse this use of OPC. ${ }^{74}$

Forced drugging in the community has thus been characterized as the "core of OPC." "7s A powerful critique of OPC argues that its effectiveness "depends on being able to compel those who resist ... psychotropic medication . . . to

\footnotetext{
${ }^{67}$ Welsch, 373 F. Supp. at 503 (emphasis added). The court noted that the evidence in the case before it reflected that such medication was used for "self-protection of residents and [because of] insufficient staffing." Id.

6Wyatt v. Stickney, 325 F. Supp. 781 (M.D. Ala. 1971), 334 F. Supp. 1341 (M.D. Ala.), 344 F. Supp. 373, 380 (M.D. Ala.), 344 F. Supp. 387 (M.D. Ala. 1972), affd sub nom. Wyatt v. Aderholt, 503 F. 2d 1305 (5th Cir. 1974). Wyatt is discussed extensively in 2 M.L. PerLin, supre note 3, 854.07-4.19.

${ }^{6}$ Wyatt, 344 F. Supp. at 400.

${ }^{70}$ The text infra accompanying notes 71-89 is generally adapted from Perlin, supra note 9, at 50-52.

${ }^{n}$ See generally, Hoge \& Appelbaum, Legal Issues in Outpatient Psychiatry, in OUTPATIENT PSYchiATRY; DiAGNOSIS AND TREATMENT 605 (A. Lazare ed. 2d ed. 1989).

${ }^{72}$ See e.g., N.C. GEN. STAT. \$122C-263(d)(1).

${ }^{73}$ See e.g., WIS. STAT. ANN. $851.20(\mathrm{dm})$ (OPC permissible if court finds dangerousness of patient 48 likely to be controlled with appropriate medication administered on an outpatient basis"); TENN. CODE ANN. 833-6-201(b) (2) (allowing OPC where patient is subject to the "obligation to participate in any medically appropriate outpatient treatment, including . . . medication ... ").

${ }^{74}$ In re Anderson, 73 Cal. App. 3d 38, 140 Cal. Rptr. 546, 550 (1977) (medication an appropriate condition of outpatient treatment). Compare In re Richardson, 481 A. 2d 473, 479 n. 5 ( D.C. 1984) ("Not every instance of the outpatient's failure to take prescribed medication or attend therapy sessions justifies the conclusion that he is not cooperating with the treatment program").

${ }^{75}$ Stefan, Preventive Commitment: The Concepts and Its Pitfalls, 11 MENT. \& PHYs. Dis. L. RPTR. 288, 294 (1987); see also, J. La Fond, "The Homeless Mentally Ill: Is Coercive Psychiatry the Answer?" (paper presented at annual meeting of the Association of American Law Schools, Section on Law and Mental Disability, January 1990, San Francisco, CA) (in outpatient settings, "[d]rugs - with all their risks - will undoubtedly be the treatment of choice"); Gelman, Mental Hospital Drugs: Professionalism and the Constitution, 72 GEo. L.J. 1725, 1750 (1984):
}

Drugs make custody possible without its traditional physical trappings. To house a drugged population, the thick walls, physical barriers, geographical isolation, and staff supervision of state mental hospitals are generally unnecessary. 
follow a prescribed regimen of care." ${ }^{\text {76 }}$ This argument must be considered in the context of recent literature that charges that community mental health services have never been truly accessible to former state hospital patients, ${ }^{77}$ and of recent case law that holds that Community Mental Health Centers (CMHCs) have the right to refuse admission to state hospital outpatients. ${ }^{78}$ If OPC's success depends on the dedication of CMHCs to "making [it] work," the concern that such facilities may pay only "lip service" to the status makes us reconsider OPC as a tool by which to enforce community drugging. ${ }^{79}$

It is also necessary to consider the interrelationship between homelessness ${ }^{80}$ and the right to refuse treatment. ${ }^{81}$ While common wisdom seems to suggest that one of the key factors in the creation of deinstitutionalization policies was the mass marketing of psychiatric drugs ${ }^{82}$ there has been virtually no exploration of the impact of forced public hospital drugging on increased homelessness.

It has been argued that side effects such as akinesia and akathesia have the inevitable effect of retarding social skill progress and of making ex-patients

\footnotetext{
${ }^{76}$ Schwartz \& Costanzo, Compelling Treatment in the Community: Distorted Doctrines and Violated Values, 20 Loy. L.A. L. Rev. 1329, 1384 (1987).
}

In one unreported case, a state administrative agency ruled that it was improper to terminate an ex-mental patient from a community mental health program because she refused to take an antipsychotic drug. In this case, the agency director found that termination was too harsh of a penalty, since there was no testimony in the record as to: (1) the effects of the drug (Haldol); or (2) the possible harm that would be caused to the petitioner or others as a result of her refusal. In re FHD 80-042, No. H.D.Y. 2400-80 (N.J. Dep't of Human Servs. Oct. 10, 1980), reported at 5 MENT. Dis. L. REP. 41 (1981).

In addition, there had been no efforts made to resolve the matter by either prescribing a different drug or a lesser amount of the drug in question. Finally, the community mental health center's contract with the state contained "no clause or provision which require[d] clients to surrender complete control of the selection of the type and amount of the medication that will be prescribed to them in order for them to remain in the program." Id.

${ }^{77}$ See E. F. Torrey, Nowhere To Go: The Tragic OdysSey of the Homeless Mentally Ill 13860 (1988).

${ }^{78}$ Rhode Island Dept. of Mental Health v. R.B., 549 A. 2d 1028, 1031 (R.I. 1988).

${ }^{79}$ Hiday \& Scheid-Cook, The North Carolina Experience With Outpatient Commitment: A Critical Appraisal, 10 INT'L J. L. \& PsYCHIATRY 215, 230-31 (1987). See generally, Perlin, supra note 49, at 121-22.

${ }^{80}$ See generally, 2 M.L. PERLIN, supra note 3, at $\$ \S 7.23-7.27$.

${ }^{81}$ See generally, Perlin, supra note 32, at 104-06.

${ }^{82}$ See e.g., E. F. TORREY, supra note 77, at 87-88 (use of drugs in state hospital "a miracle"). Compare id. at 158 (criticizing court decisions such as Rogers v. Okin, 478 F. Supp. 1342 (D. Mass. 1979), mod. 634 F. 2d 650 (1 Cir. 1980), vacated and remanded 457 U.S. 291 (1982), on remand 738 F. 2d 1 (1984), and Rennie v. Klein, 462 F. Supp. 1131 (D.N.J. 1978), suppl. 476 F. Supp. 1294 (D.N.J. 1979), mod. 653 F. $2 d 836$ (3 Cir. 1981), vacated and remanded 458 U.S. 1191 (1982), on remand 720 F. 2d 266 (3 Cir. 1983), for permitting mentally ill individuals "once released from a hospital, to remain free and psychotic in the community"), to Gelman, supra note 75, at 1727 n. 23 ("Drugging of the mentally ill in the 'community' is all but universal"). For a comprehensive analysis of all related issues involved in right to refuse medication decision making in community settings, see Schwartz \& Costanzo, supra note 80 , For a fuller consideration of this issue, see Perlin, Book Review of A.B. Johnson, Out of Bedlam: The Truth ABout DeinstituTIONAlization (1990)), 8 N.Y. L. SCH. J. Hum. RTs. 557 (1991); Gould, "Madness in the Streets" Rides the Waves of Sanism (book review of R. J. ISAaC \& V.C. ARMat, Madness IN THE STReETS: How Psychiatry and the LAw ABandoned the Mentally Ill (1990)), 9 N.Y. L. SCH. J. HUM. RTs. 567 (1992). 
even less employable once they are deinstitutionalized..$^{83}$ Notwithstanding the drugs' apparent effectiveness in reducing the floridity of symptomatology and lessening the excesses of psychic pain, ${ }^{84}$ the linkage between these drug side effects, the failure of patients to be meaningfully reintegrated into society after their release, and homelessness has not yet been critically considered. The linkage may be especially pernicious in light of the parallel literature illuminating the ways in which institutional dependency progressively leads to losses of social and vocational competencies, precisely the sort of "competencies" that are essential if homeless individuals are to reintegrate themselves meaningfully into mainstream society. ${ }^{85}$

There is now some hard evidence that some deinstitutionalized homeless individuals remain on the streets to avoid regimens of compulsory drugging in hospitals. ${ }^{86}$ Parenthetically, other researchers have learned that the deinstitutionalized homeless will accept medication in social service settings. ${ }^{87}$ It is unclear whether other evidence-that the deinstitutionalized homeless reject the alternative of mental hospitals ${ }^{88}$ but frequently seek out medical care in general

${ }^{83}$ Compare Rennie, 462 F. Supp, at 1146 (ikelihood of patient contracting tardive dyskinesia rajses question of whether "the cure would be worse than the illness"); Bellack \& Mueser, $A$ Comprehensive Treatment Program for Schizophrenia and Chronic Mental Illiness, 22 Community Mental HeAlth J. 175,177 (1980) (as many as $50 \%$ of schizophrenics may not benefit from antipsychotic medication; such medications do not help patients "develop skills of daily living that enhance the quality of life").

${ }^{4}$ See Rennie, 462 F. Supp. at 1137:

Psychotropic drugs are effective in reducing thought disorders in a majority of schizophrenics. With first admission patients, success rates as high as $95 \%$ have been obtained . . . Success rates are less impressive with chronic patients ... However, no other treatment modality has achieved equal success in the treatment of schizophrenia . . .

${ }^{85}$ C. Keisler \& A. Sibulkin, Mental Hospitalization: Myths and Facts about a National CRISIS 148 (1987), discussing McEwen, Continuities in the Study of Total and Non-total Institutions, 6 AM. REv. SOCIOL. 143 (1980), and Goldstein, The Sociology of Mental Health and Illness, 5 AM. Rev. SOciol. 381 (1979).

${ }^{26}$ See Fischer \& Breakey, Homelessness and Mental Health: An Overview, 14 InT'L J. Mental Health 6,29 (1986), finding that a proportion of the mentally ill homeless have "opted out" of the mental health system, preferring the "life of the streets" to the alternative of institutional life, and have elected to "live with" the symptoms of mental illness rather than suffer from the unwanted side effects of antipsychotic medication. This result may be seen, depending upon the reader's perspective, as good judgment or as evidence of the degree to which mental illness has impaired the individual's thought systems. See id. (of a series of 15 problem areas, mental illness was rated as 13 th in importance by the homeless). See also, Gelberg, Linn \& Leake, Mental Health, Alcohol and Drug Use, and Criminal History Among Homeless Adults, 145 AM. J. Psychiatry 191, 193 (1988) (deinstitutionalized patients the least likely of the homeless to sleep in emergency shelters).

${ }^{7}$ Arce, Tadlock, Vergare \& Shapiro, A Psychiatric Profile of Street People Admitted To an Emergency Shelter, 34 HOSP. \& COMMUN. PsYCHIATRY 812 (1983) $(86 \%$ of the homeless mentally ill were willing to comply with psychotropic medications in community support service settings); see generally Turner \& TenHoor, The NIMH Community Support Program: Pilot Approach to a Needed Sacial Reform, 4 SCHIZ. Bull. 319 (1978).

${ }^{81}$ See Farr, A Mental Health Treatment Program for the Homeless Mentally Ill in the Los Angeles Skid Row Area, in Treating THE HOMELESS 64, 71 (B.E. Jones ed. 1986) (the "vast majority" of population studied "would rather live in filth and be subjected to beatings and violence than to be institutionalized, even in our finest mental hospitals") (emphasis added). 
hospitals $^{89}-$ can fully explain this paradox. It is clear, though, that further attention must be paid to this inquiry.

(b) Involuntary civil commitment. ${ }^{90}$ The only important issue being considered in the involuntary civil commitment process in recent reported appellate decisions is whether a patient is "competent" to make the "right choice" and self-medicate in the community if commitment is not ordered. ${ }^{91}$ Here, courts regularly and routinely weigh experts' predictions of a patient's potential refusal to take antipsychotic medication in a community setting as probativethe most probative-evidence on the question of whether involuntary civil commitment should be ordered.

Most of the reported cases rely here on psychiatric "expert" predictions as the dispositive evidence. ${ }^{92}$ Although there is widespread belief that refusal to take such medication will make some patients more dangerous, ${ }^{93}$ there is absolutely no evidence that psychiatrists have any special ability to predict community medication compliance. ${ }^{94}$ There is also a body of evidence that suggests that this population is comprised of precisely those individuals that many community mental health centers do not want to treat. ${ }^{95}$

Nevertheless, involuntary civil commitment is regularly ordered because testifying experts find it "doubtful" that the patient would self-medicate in the community. ${ }^{96}$ Thus, where the operative state statute included a presumption that the subject of the commitment petition did not require treatment, ${ }^{97}$ and where civil commitment required clear and convincing evidence of a "serious

${ }^{89}$ See Silver, Voluntary Admission to New York City Hospitals: The Rights of the Mentally IIl Homeless, 19 Colum. Human RTs. L. REv. 399, 400-01 n. 3, 402-03 n. 5 (1988) (substantial numbers of homeless mentally ill seek treatment in emergency rooms of city general hospitals).

${ }^{90}$ The material infra accompanying notes $91-100$ is generally adapted from Perlin, supra note 49 , manuscript at 83-92.

${ }^{91}$ See generally, cases discussed in 1 M.L. PerLIN, supra note 3, \$3.45, at 71-73, nn. 726.1-741 (1992 pocket part); Perlin, supra note 32, at 116-17 nn. 306-08; Perlin, supra note 9, at 50-51.

${ }^{92}$ For an example of a court rejecting this line of thinking, see In re J.S.C., 812 S.W. 2d 92, 95-96 (Tex. App. 1991) (testimony that patient will deteriorate if he fails to take medication insufficient basis upon which to sustain involuntary civil commitment determination).

${ }^{93}$ Scheid-Cook, Commitment of the Mentally Ill to Outpatient Treatment, 23 COMMUN. MENT. HeALTH J. 173, 180 (1987).

${ }^{94}$ The literature reveals no studies on this question. A recent reconsideration of dangerousness studies lists over $\mathbf{4 0}$ factors to be considered by experts in assessing probabilities of an individual's future violence; community medication compliance is not included. Palermo, Liska, Palermo \& Del Forno, On the Predictability of Violent Behavior: Considerations and Guidelines, 36 J. FORENS. SCI. 1435, 1440 (1991), and see id. at 1439 ("One should not deduce the possibility for future dangerousness from an isolated individual trait").

${ }^{95}$ Scheid-Cook, supra note 93, at 181-82, citing, inter alia, Stern \& Minkoff, Paradoxes in Programming for Chronic Patients in a Community Clinic, 30 Hosp. \& Commun. Psychiatry 613 (1979); see also, Schwartz \& Costanzo, supra note 76, at 1386-89; A. B. JoHNSON, supra note 82, at 78.

${ }^{9}$ In Interest of L.B., 452 N.W. 2d 75, 77 (N. Dak. 1990). In the same case, an additional expert had testified that the patient did not suffer from a mental illness.

A patient's refusal to accept antipsychotic medication is also seen as a sufficient basis upon which to reject voluntary commitment status. See e.g., Matter of J.B., 705 P. 2d 598, 602 (Mont. 1985); Wessel v. Pryor, 461 F. Supp. 1144, 1148 (E.D. Ark. 1978).

${ }^{97}$ N.D.C.C. \$25-03.1.19; In re Kupperion, 331 N.W. 2d 22, 26 (N.Dak. 1985). 
risk of harm," ${ }^{98}$ a commitment order was affirmed where the experts testified that the patient would "benefit" from medication and that the "only way" such medication could be provided in a supervised basis was in a "structured residential type of placement" and that "if she was discharged from the hospital, she would quit taking her medication."

\section{In Criminal Law Settings ${ }^{100}$}

Defendants Awaiting Trial. Prior to 1987, medication cases involving defendants awaiting IST determinations had "resulted in a series of apparently random decisions from which almost no doctrinal threads could be extracted," leading to "significant and genuine confusion" in this area. ${ }^{101}$ More recently, though, two separate decisions in one case - with radically different opinions appear to have brought some measure of coherence to this area. ${ }^{102}$

In 1987, a panel of the Fourth Circuit Court of Appeals issued the first decision in United States $v$. Charters ${ }^{103}$ (Charters I) on the right of a federal pretrial detainee to refuse psychotropic medication. Charters $I$ rejected the notion that the "exercise of professional judgment standard" articulated by the Supreme Court in Youngberg v. Romeo applied to antipsychotic medication cases, resurrected right-to-privacy and freedom-of-thought-process arguments that had been generally abandoned in the years since the Supreme Court's decision in Mills v. Rogers, established a right to be free from unwanted physical intrusion as an integral part of an individual's constitutional freedoms, and articulated a complex substituted judgment-best interests methodology to be used in right to refuse treatment cases. ${ }^{10}$

On en banc rehearing, the full Fourth Circuit vacated the panel decision (Charters II), "suggesting that the panel was wrong about almost everything." ${ }^{105}$ Although it agreed that the defendant possessed a constitutionally retained interest in freedom from bodily restraint that was implicated by the forced administration of psychotropic drugs and was protected "against arbitrary and capricious action by government officials,"

\footnotetext{
Defined as a "substantial deterioration in mental health which would predictably result in dangerousness to that person, others, or property, based upon acts, threats, or patterns in the person's treatment, current condition, and other relevant factors. N.D.C.C. $\$ 25-03.1-02(10)$ (d).

"Interest of R.N., 453 N.W. 2d 819, 822 (N.D. 1990).

${ }^{100}$ The material infra accompanying notes $101-46$ is generally adapted from Perlin, supra note 1, manuscript at 4-13.

${ }^{101}$ Perlin, supra note 10, at 963; compare e.g., State v. Hayes, 118 N.H. 458, 389 A. 2d 1379 (1978), to Whitehead v. Wainwright, 447 F. Supp. 898 (M.D. Fla. 1978), vacated and remanded on other $8 d s ., 609$ F. 2d 223 (Sth Cir. 1980).

${ }^{102}$ But compare Riggins v. Nevada, 112 S. Ct. 1810 (1992).

${ }^{103} 829$ F. 2d 479 (4th Cir. 1987) (Charters D), on rehearing, 863 F. 2d 302 (4th Cir. 1988) (en banc) (Charters II), cert. den., 110 S. Ct. 1317 (1990).

${ }^{104}$ See generally, Perlin, supra note 10; 2 M.L. PerLIN, supra note 3, at $\$ 5.64$.

${ }^{103}$ Perlin, supra note 10, at 965.

${ }^{106}$ Charters, 863 F. 2 d at 306.
} 
institutional administrative procedures were adequate to protect the defendant's due process interests. It applied the "substantial professional judgment" test of Youngberg, and limited questioning of experts to one matter: "[W]as this decision reached by a process so completely out of bounds as to make it explicable only as an arbitrary, nonprofessional one?"107 Although the court briefly acknowledged the possibility of side effects (a factor stressed heavily in Charters $I$, it quickly dismissed the magnitude of their potential harm by noting that they were simply "one element" to be weighed in a best-interests decision. Here, the court conceded that it did not do an "exhaustive analysis" of the conflicting literature before it, demurring to that literature's importance:

It suffices to observe that, while there is universal agreement in the professional discipline that side effects always exist as a risk, there is wide disagreement within those disciplines as to the degree of their severity. ${ }^{108}$

The two views of the rights of pretrial detainees to refuse medication reflected in Charters I and Charters II could not be more diametrically opposed. Also, the ultimate en banc decision has led to some important strategic decision making. Although, as a federal detainee, Charters was forced to litigate in federal court, in cases where litigants do have an option of availing themselves of a state forum, it is now likely they will choose that jurisdictional alternative. Charters II thus appeared to "signal the death knell for the litigation of right to refuse treatment issues in the federal forum" in cases in which litigants retain discretion as to where to sue. ${ }^{109}$

Defendants Permanently IST. In Jackson v. Indiana, the Supreme Court held that it violated due process to commit an individual for more than the "reasonable period of time" necessary to determine "whether there is a substantial chance of his attaining the capacity to stand trial in the foreseeable future." ${ }^{110}$ If there were to be no such chance, a defendant originally committed pursuant to an IST finding would either be subjected to the civil commitment process or released; once having been "Jacksonized" (that is, having had their criminal indictments dismissed but remaining in need of hospitalization), such patients must be treated like other civil patients. ${ }^{111}$

There has been virtually no case law on the rights of Jacksonized patients to refuse medication; neither of the two pertinent cases substantially illuminates the underlying doctrinal issues. ${ }^{112}$ Charters II should not have a significant

\footnotetext{
${ }^{107} I d$. at 313.

${ }^{108} I d$. at $310-11$.

${ }^{109}$ Perlin, supra note 10, at 994 . On the pretextual nature of Charters II, see Perlin, supra note 49, manuscript at 72-73.

${ }^{110} 406$ U.S. 715, 733 (1972).

${ }^{11}$ See Perlin, supra note 9, at 48-49.

${ }^{112}$ See e.g., DeAngelas v. Plaut, 503 F. Supp. 775 (D. Conn. 1980); Mannix v. State, 621 S.W. 2d 222 (Ark. 1981); Perlin, supra note 9, at 62-63 n. 115; 2 M.L. PerLIN, supra note 3, 85.65, at 75 (1992 pocket part).
} 
impact on this population who should be treated like other civil patients (due to the dismissal of the underlying indictments that triggered their entry into the criminal trial process). Thus, it can be expected that future developments here will track similar developments involving involuntarily committed civil patients, and more closely adhere to the "expanded due process" model.

Otherwise Awaiting Trial in Jails. Cases involving jailed pretrial detainees have generally interpreted the right to refuse treatment broadly. In Bee $v$. Greaves, the Tenth Circuit ruled that "less restrictive alternatives" should be ruled out before psychotropic medication is involuntarily administered to a jailed detainee; ${ }^{113}$ other courts have similarly ruled that the availability of a less intrusive alternative that could have been employed by defendants must be considered in the determination of such a case. ${ }^{114}$ Bee has been read by commentators as being of potentially "great precedential value" because it refused to "completely preclude judicial intrusions into the management of detention facilities." 115 There has been, somewhat surprisingly, little follow-up litigation after Bee.

Defendants Pleading Insanity. (a) At trial. Courts have also considered the impact of involuntary medication on a defendant's right to the presentation of an insanity defense at trial. ${ }^{116}$ Several have ruled that a defendant has a fundamental right to present his demeanor to the jury in an unmedicated state when sanity is at issue; ${ }^{117}$ others have found that a defendant has a right to inform the jury as to the effects of such medication during trial, ${ }^{118}$ and at least one has found that a defendant has a right to be unmedicated at a pretrial psychological evaluation. ${ }^{119}$

Mental disability law jurisprudence seemed to take a dramatic turn recently, though, in Riggins $v$. Nevada. ${ }^{120}$ Riggins held that the use of antipsychotic drugs violated defendant's right to fair trial (at which he had raised the insanity defense), focusing on the drugs' potential side effects, and construing the court's previous decision in Washington $v$. Harper ${ }^{121}$-limiting the rights of convicted prisoners to refuse medication - to require "an overriding justification and a determination of medical appropriateness" prior to forcibly administering

\footnotetext{
${ }^{113}$ Bee v. Greaves, 744 F. 2 d 1387, 1396 (10th Cir. 1984), cert. den., 469 U.S. 1214 (1985).

${ }^{114}$ Osgood v. District of Columbia, 567 F. Supp. 1026 (D.D.C. 1983).

${ }^{11}$ Note, Bee v. Greaves: Pretrial Detention and the Constitutional Right to Refuse Antipsychotic DrugsA Missed Opportunity to Protect Fundamental Rights, 22 AM. CRIM. L. REv. 836, 853, 856 (1985).

${ }^{116}$ See e.g., Note, Medical Law-Unmedicated Defendants: The Two Prong Dilemma, 7 West. N. Eng. L. Rev. 995 (1985); Note, The Identification of Incompetent Defendants: Separating Those Unfit for Adversary Combat From Those Who are Fit, 66 KY. L.J. 666 (1987).

${ }^{117}$ See e.g., Commonwealth v. Louraine, 390 Mass. 28, 453 N.E. 2d 437 (1983); State v. Maryott, 6 Was. App. 96, 492 P. 2d 239 (1971).

${ }^{11}$ See e.g., People v. Hardesty, 139 Mich. App. 124, 362 N.W. 2d 787 (1984); In re Pray, 133 Vt. 253, 336 A. 2d 174 (1975).

${ }^{119}$ People v. Matthews, 148 A.D. 2d 272, 544 N.Y.S. $2 d 398$ (1989), app'l dismissed, 74 N.Y. 2d 950, 550 N.Y.S. 2d 585, 549 N.E. 2d 487 (1989).

${ }^{120} 112$ S. Ct 1810 (1992). See generally, Perlin \& Dorfman, supra note 6.

${ }^{121} 494$ U.S. 210 (1990); see 2 M.L. PERLIN, supra note 3, 85.64A, at $62-74$ (1992 pocket part).
} 
antipsychotic medications to a prisoner. ${ }^{122}$ It focused on what might be called the "litigational side effects" of antipsychotic drugs, and discussed the possibility that the drug use might have "compromised" the substance of the defendant's trial testimony, his interaction with counsel, and his comprehension of the trial. ${ }^{123}$

In a concurring opinion, Justice Kennedy (the author of Harper) took an even bolder position. He would not allow the use of antipsychotic medication to make a defendant competent to stand trial "absent an extraordinary showing" on the state's part, and noted further that he doubted this showing could be made "given our present understanding of the properties of these drugs." 24 Justice Thomas dissented, suggesting (i) the administration of the drug might have increased the defendant's cognitive ability, ${ }^{125}$ (ii) since Riggins had originally asked for medical assistance (while a jail inmate, he had "had trouble sleeping" and was "hearing voices"), it could not be said that the state ever "ordered" him to take mediation, ${ }^{126}$ (iii) if Riggins had been aggrieved, his proper remedy was a $\$ 1983$ civil rights action, ${ }^{127}$ and (iv) under the majority's language, a criminal conviction might be reversed in cases involving "penicillin or aspirin." 128

(b) Following an NGRI verdict. While individuals who had been previously adjudicated NGRI were members of some early class actions challenging institutional drugging practices, ${ }^{129}$ there has been "remarkably" little litigation on behalf of this population. ${ }^{130}$ The most recent important case, a Maryland state decision, construed Harper to guard against the arbitrary administration of antipsychotic drugs in the context of NGRI insanity acquittees, and declared unconstitutional a state statute that failed to provide such a patient with the rights to adequate notice, to be present, to present evidence, and to crossexamine witnesses at a drug refusal hearing, and to have the right to judicial review of an adverse decision at such a hearing. ${ }^{131}$ The Maryland court's reliance on both state and federal constitutions, thus suggests that lower courts may limit Harper to the specific population in that case (convicted prisoners), even where the patient's original confinement stems from the criminal trial process.

Convicted Prisoners. The Supreme Court's decision in Washington $v$. Harper sharply limited the right of convicted felons to refuse treatment under

\footnotetext{
${ }^{122}$ Riggins, $112 \mathrm{~S}$. Ct at 1815.

${ }^{123}$ Id. at 1816.

${ }^{124}$ Id. at 1817 (Kennedy, J. concurring).

${ }^{125}$ Id. at $1822-23$ (Thomas, J., dissenting).

Trial testimony had indicated that Riggins' daily drug regimen $(800 \mathrm{mgs}$. of Mellaril) was enough to "tranquilize an elephant." Id at 1819 (Kennedy, J., concurring), quoting trial record.

${ }^{126}$ Id. at 1823-24 (Thomas, J., dissenting).

${ }^{127}$ Id. at 1825-26. At his trial, Riggins had been sentenced to death.

${ }^{128} I d$. at 1826.

${ }^{129}$ See e.g., Davis v. Watkins, 384 F. Supp. 1196 (N.D. Ohio 1974); Davis v. Hubbard, 506 F. Supp. 915 (N.D. Ohio 1980).

${ }^{130}$ Perlin, supra note 9, at 47.

${ }^{131}$ Williams v. Walzack, 319 Md. 485, 573 A. 2d 809 (1990), reconsid. den. (1990).
} 
the federal constitution. While the court agreed that prisoners (like all other citizens) possessed a "significant liberty interest" in avoiding the unwanted administration of antipsychotic drugs, ${ }^{132}$ it found that the need to balance this interest with prison safety and security consideration would lead it to uphold a prison rule regulating drug refusals as long as it was "reasonably related to legitimate penological interest," even where fundamental interests were otherwise implicated. ${ }^{133}$ Thus, a state policy - that provided for an administrative hearing (before a tribunal of mental health professionals and correctional officials) at which there was neither provision for the appointment of counsel nor regularized external review - passed constitutional muster. ${ }^{134}$

In a sharply worded opinion, Justice Stevens dissented, arguing that the refusal of medication was "a fundamental liberty interest deserving the highest order of protection," especially where the imposition of such medications might create "a substantial risk of permanent injury and premature death."

Harper clarifies an important strand of supreme court jurisprudence: "prison security concerns will, virtually without exception, trump individual autonomy interests." 136 Pre-Harper state cases had given prisoners far broader rights to refuse under state constitutional provisions, ${ }^{137}$ and the first postHarper scholarly analysis suggests that its influence on future state law developments will likely be "only hortatory"; ${ }^{138}$ the Maryland NGRI decision in Williams $v$. Walczak appears to bear this out.

Perhaps the most interesting developments come in the way the Supreme Court chose to read Harper in Riggins, just 2 years later. The difference in outcomes may be traced to the difference in court perspectives; Riggins treated Harper as a prison security case while it read Riggins as a fair trial case; yet, this difference in the litigants' legal status self-evidently has no effect on the physiological or neurological potential impact of the arugs in question. Nevertheless, side effects language in Harper (subordinated there because of security reasons) is privileged in Riggins (where such issues are absent) by nature of the court's consideration of the question in the context of a fair trial issue. Justice Thomas's opinion raises grave issues for defense counsel; had his position prevailed, would concerned and competent defense lawyers feel as if they were assuming a risk in ever seeking psychiatric help for an awaiting-trial defendant ${ }^{139}$ His analogizing antipsychotic drug side effects to penicillin or aspirin may be disingenuous or it may be cynical. What is clear is that nowhere

\footnotetext{
${ }^{132}$ Harper, 494 U.S. at 221, quoting Vitek v. Jones, 445 U.S. 480, 488-91 (1980).

${ }^{133}$ Id. at 223.

${ }^{134}$ Id. at 223-24.

${ }^{133}$ Id. at 241 (Stevens, J., concurring in part \& dissenting in part).

${ }^{136} 2$ M.L. PerLIN, supra note 3, \$5.64A, at 72 (1992 pocket part).

${ }^{137}$ See e.g., Keyhea v. Rushen, 178 Cal. App. 3d 526, 223 Cal. Rptr. 746 (1986); Large v. Superior Court, 148 Ariz. 229, 714 P. $2 d 399$ (1986).

${ }^{138}$ Appelbaum, Washington v. Harper: Prisoners' Right to Refuse Antipsychotic Medication, 41 HosP. \& COMMUN. PSYCHIATRY 731, 732 (1990).

${ }^{139}$ Compore Buchanan v. Kentucky, 483 U.S. 402 (1987) (no error to admit, in rebuttal of defendant's "extreme emotional disturbance" defense, report prepared following pretrial detainee's request to be treated at state hospital pending trial), discussed in 3 M.L. PerLIN, supra note 3, \$16.04A, at 425-29.
} 
in the lengthy corpus of "right to refuse treatment" litigation is this position ever seriously raised. ${ }^{140}$

Competency to Be Executed. Still undecided is the important question of whether a state can involuntarily medicate an individual under a death sentence so as to make him competent to be executed. After the Supreme Court determined that an incompetent defendant cannot be executed ${ }^{141}$ (a holding that it did not extended to cases involving mentally retarded individuals), ${ }^{142}$ it agreed to hear, in Perry $v$. Louisiana, a case that posed this precise question. ${ }^{143}$

In Perry, the Louisiana state courts had found that any due process right the capital defendant might have was outweighed by two compelling state interests: the provision of psychiatric care, and the carrying out of a valid death penalty. ${ }^{144}$ After the Supreme Court originally decided to hear the case (to determine whether the Eighth Amendment's proscription against cruel and unusual punishment prohibits states from so medicating death row inmates), it ultimately vacated the lower court's decision and remanded for further proceedings in light of its decision in Harper on the scope of a convicted prisoner's right to refuse. ${ }^{145}$

The Supreme Court's reasoning in this case is not clear. It may be that the justices felt, upon reflection, that the only issue presented was that of forcible medication (finding the execution consequences irrelevant), and it was thus necessary for the state court to consider, after Harper, whether the difference in long-term harm in a case such as Perry (his execution) outweighed the state's interest in involuntarily medicating him. ${ }^{146}$ Interestingly, the Supreme Court had decided Harper a week before it chose to grant certiorari in Perry; its decision to vacate and remand for consideration of Harper may thus mean that the court could not-or would not - resolve the difficult tensions presented by such a case.

\section{Decoding the Right to Refuse Treatment}

As I have sought to demonstrate, the jurisprudence of the right to refuse treatment is complex. Separate bodies of doctrine have developed in parallel court systems and in cases involving civil and criminal litigants. The Supreme

${ }^{140}$ The only case in which a similar issue is raised is Matter of Salisbury, 138 Misc. 2d 361, 524 N.Y.S. 2d 352, 354 (Sup. Ct. 1988), holding that prior court authorization was not necessary before a state mental hospital could administer antibiotics to a patient, citing "overwhelming public policy considerations" that made it "imperative" that hospitals could perform such "routine, accepted, nonmajor medical treatment which poses no significant risk, discomfort, or trauma to the patient." Salisbury has never been cited in any subsequent case nor has it been mentioned in the law review literature.

${ }^{141}$ Ford v. Wainwright, 477 U.S. 399 (1986).

${ }^{142}$ See Penry v. Lynaugh, 492 U.S. 302 (1989).

${ }^{143} 110$ S. Ct. 1317, 56 U.S.L.W. 3584 (1990).

${ }^{144}$ State v. Perry, 543 So. $2 d 487$ (La. 1989), rehearing den., 545 So. $2 d 1049$ (1989).

${ }^{145}$ Perry v. Louisiana, 111 S. Ct. 449 (1990), reh. denied, 111 S. Ct. 804 (1991). The Louisiana Supreme Court subsequently has ruled that drugging Perry to make him competent to be executed would violate the state constitution. State v. Perry, 608 So. 2d 594 (La. 1992).

${ }^{146} 3$ M. L. PERLIN, supra note 3, 817.06B, at 208 (1992 pocket part); Supreme Court Sidesteps Issue of Restoring Inmates' Competency to Allow Execution, Psychiatric News (Dec. 21, 1990). 
Court's decisions in Youngberg v. Romeo and Mills v. Rogers led to an exodus from federal courts, but its recent opinion in Riggins $v$. Nevada may augur a return to that forum. Some courts choose to read the social science literature on side effects carefully while others profess that they are unable to make meaningful distinctions among the data. In 2 years time, the Supreme Court has nearly done a complete "about face" in its reading of the same evidence. There has been virtually no litigation in cases involving some of the most important "categories" of potential right to refuse litigants in "other" settings. The vast majority of litigation has involved antipsychotic drugs, although commentators and a handful of cases raise the question of the application of the doctrine to a full range of other treatments.

Is it possible to extract meaningful doctrinal coherence from these conflicting findings? My reading of nearly 2 decades of legal developments in this area suggests that sense can be made only if we first look at a question that is rarely asked in this context: why has the law developed as it has in this volatile area?

And here I think we can make some sense, if we look at the roots of judicial attitudes toward decision making in such cases. To do this, I turn to a series of constructs that should help illuminate this answer-to heuristics, to sanism, and to pretextuality. After I consider their impact, I will place my findings in a therapeutic jurisprudence filter in an effort to "decode" right to refuse treatment law.

\section{Jurisprudential Constructs}

Heuristics. ${ }^{147}$ "Heuristics" is a cognitive psychology construct that refers to implicit thinking devices that individuals use to oversimplify complex, information-processing tasks. The use of these heuristic devices often leads to distorted and systematically erroneous decisions, and causes decision makers to "ignore or misuse items of rationally useful information." 148 The "vividness" heuristic thus teaches us that one single vivid, memorable case overwhelms mountains of abstract, colorless data upon which rational choices should be made. ${ }^{149}$ It is important to understand that mental health professionals are just as susceptible to the use of these devices as are judges, jurors, legislators, or lay persons. ${ }^{150}$

\footnotetext{
${ }^{147}$ The material infra accompanying notes $148-51$ is generally adapted from Perlin, supra note 49, manuscript at 79-82.

${ }^{143}$ See e.g., Perlin, supra note 10, at 966 n. 46, quoting, in part, Carroll \& Payne, The Psychology of the Parole Decision Process: A Joint Application of Attribution Theory and Information-Processing Psychology, in Cocnition and Social Behavior 13, 21 (J. Carroll \& J. Payne eds. 1976).

${ }^{14}$ Rosenhan, Psychological Realities and Judicial Policy 19 STAN. LAw. 10, 13 (1984).

${ }^{150}$ See e.8., C. Webster, R. Menzies \& M. Jackson, Clinical Assessments Before Trial 121 (1982); Jackson, The Clinical Assessment and Prediction of Violent Behavior: Toward a Scientiflc Analysis, 16 CRIM. Just. \& BeHAv. 114 (1989); Jackson, Psychiatric Decision-Making for the Courts: Judges, Psychiatrists, Lay People? 9 INTL J. L. \& PsychIATRY 507 (1986). On Juror use of heuristic reasoning, see Torrey, When Will We Be Believed? Rape Myths and the Idea of a Fair Trial in Rape Prasecutions, 24 U. CAL. Davis L. REv. 1013, 1050 (1991); Koehler \& Shaviro, Veridical Verdicts: Increasing Verdict Accuracy Through the Use of Overtly Probabillstic Evidence and Methods, 75 CORNELL L. Rev. 247, 264-65 (1990); see also, Roberts \& Golding, The Social Construction of Criminal Responsibility and Insanity, 15 LAW \& HUM. BeHAv. 349, 372 (1991) (Jurors' preexisting attitudes toward insanity defense strongest predictor of individual verdicts). On legislative use of heuristic reasoning, see Perlin, supra note 32, at 128.
} 
Thus, through the "availability" heuristic, we judge the probability or frequency of an event based upon the ease with which we recall it. Through the "typification" heuristic, we characterize a current experience via reference to past stereotypical behavior; through the "attribution" heuristic, we interpret a wide variety of additional information to reinforce preexisting stereotypes; through the "myth of particularistic proofs," we erroneously assume that casespecific (anecdotal) information is qualitatively different from base-rate (statistical) information. Through the "hindsight bias," we exaggerate how easily we could have predicted an event beforehand. Through the "outcome bias," we base our evaluation of a decision on our evaluation of an outcome. ${ }^{151}$

Sanism. ${ }^{252}$ "Sanism" is an irrational prejudice of the same quality and character of other irrational prejudices that cause (and are reflected in) prevailing social attitudes of racism, sexism, homophobia, and ethnic bigotry. ${ }^{153}$ It infects both our jurisprudence and our lawyering practices. ${ }^{154}$ Sanism is largely invisible and largely socially acceptable. It is based largely upon stereotype, myth, superstition, and deindividualization, and is sustained and perpetuated by our use of false "ordinary common sense" ${ }^{\text {"155 }}$ and heuristic reasoning in an unconscious response to events both in everyday life and in the legal process.

${ }^{151}$ See generally, Perlin, Psychodynamics and the Insanity Defense: "Ordinary Common Sense" and Heuristic Reasoning, 69 NEB. L. REV. 3, 13-18, 29-30 (1990), citing, inter alia JUDGMENT UNDER UNCBRTAINTY: Heuristics AND Blases (D. Kahneman, P. Slovic \& A. Tversky eds. 1982) (JuDGMENT); S. Brehm \& J. Brehm, Psychological Reactance: A THEORY of Freedom and Control (1981); $R$. NisBetT \& L. ROSS, HuMAN INFERENCE: STRATEOIES AND SHORTCOMINGS OF SOCIAL JUDOMENT (1980); Reasonino, Inference, and Judgment in Clinical Psychology (D. Turk \& P. Salovey eds. 1988) (all discussing heuristics in general); Bersoff, Judicial Deference to Nonlegal Decisionmakers: Impasing Simplistic Solutions on Problems of Cognitlve Complexity in Mental Disability Law, 46 S.M.U. L. REV. 329 (1992) (same); Doob \& Roberts, Social Psychology, Social Attitudes and Attitudes Toward Sentencing, 16 CANAD. J. Bbehav. SCI. 269 (1984) (vividness effect); Diamond \& Stalans, The Myth of Judicial Leniency. in Sentencing, 7 Behav. SCI. \& L. 73 (1989) (same); Van Zandt, Common Sense Reasoning, Social Change, and the Law, 81 Nw. U. L. Rev. 894 (1988) (typification); Kelley, The Process of Causal Attribution, 28 AM. Psychologist 107 (1973) (attribution); Russell, The Causal Dimension Scale: A Measure of How Individuals Perceive Causes, 42 J. PERsonAliTy \& Soc'L Psycholooy 1137 (1982) (same); Saks \& Kidd, Human Information Processing and Adjudication: Trial by Heuristics, 15 LAW \& Soc'Y RBV. 123, 151 (1980-81) (particularistic proofs); Arkes, Principles in Judgment/Decision Making Research Pertinent to Legal Procedures, 7 BEHAv. SCl. \& L. 429 (1989) (hindsight and outcome biases); Fischoff, Hindsight $\neq-$ Foresight: The Effect of Outcome Knowledge on Judgment Under Uncertainty, $1 \mathrm{~J}$. Exper. Psychology: Hum. Percept. \& Perform. 288 (1985) (both biases); Dawson Arkes, Siciliano, Blinkhorn, Lakshmanan \& Petrelli, Hindsight Bias: An Impediment to Accurate Probability Estimation in Clinicopathologic Conferences, 8 MED. DECIS. MAKINg 259 (1988) (hindsight bias); Baron \& Hershey, Outcome Bias in Decision Evaluation, 54 J. Personal. \& Soc'L Psychology 569 (1988).

${ }^{152}$ The material infra text accompanying notes 153-66 is generally adapted from Perlin, On "Sanism," 46 S.M.U. L. Rev, 373-77, 397-98 (1992), Perlin, supra note 49, manuscript at 78-82 and Perlin \& Dorfman, supra note 6, manuscript at 17-21.

${ }^{153}$ The classic study is G. Allport, The Nature of Prejudice (1955).

${ }^{154}$ The phrase "sanism" was, to the best of my knowledge, coined by Dr. Morton Birnbaum. See Birmbaum, The Right to Treatment: Some Comments on its Development, in MEDICAL, MORAL AND LEGAL ISSUES IN Health Care 97, 106-07 (F. Ayd ed. 1974); Koe v. Califano, 573 F. 2d 761, 764 n. 12 (2d Cir. 1978). I discuss this insight of Birnbaum's in Perlin, supra note 32, at 92-93.

${ }^{155}$ See Perlin \& Dorfman, supra note 6, manuscript at 21-22; Perlin,supra note 49, manuscript at 28 n. 69 ; see generally, Sherwin, Dialects and Dominance: $A$ Study of Rhetorical Fields in the Law of Confesslons, 136 U. PA. L. REV. 729 (1988) (discussing "ordinary common sense" [OCS]). 
Judges are not immune from sanism. "[E]mbedded in the cultural presuppositions that engulf us all, ${ }^{\text {n156 }}$ they express discomfort with social science ${ }^{157}$ (or any other system that may appear to challenge law's hegemony over society) and display skepticism about new thinking; this discomfort and skepticism allow them to take deeper refuge in heuristic thinking that perpetuates the myths and stereotypes of sanism. ${ }^{158}$

Judges reflect and project the conventional morality of the community, and judicial decisions in all areas of civil and criminal mental disability law continue to reflect and perpetuate sanist stereotypes. ${ }^{139}$ Their language demonstrates bias against mentally disabled individuals ${ }^{160}$ and contempt for the mental health professions. ${ }^{161}$ At least one court has, without citation to any authority, found that it is less likely that medical patients will "fabricate descriptions of their complaints" than will "psychological patients."162 Another court has likened psychiatric predictivity of future dangerousness to predictions made by an oncologist as to consequences of an untreated and metastasized malignancy, ${ }^{163}$ in spite of the overwhelming weight of clinical and behavioral literature that concludes that psychiatrists are far more often incorrect in predicting dangerousness than they are accurate. ${ }^{164}$

Courts often appear impatient with mentally disabled litigants, ascribing their problems in the legal process to weak character or poor resolve. Thus, a popular sanist myth is that: "Mentally disabled individuals simply don't try hard enough. They give in too easily to their basest instincts, and do not exercise appropriate self-restraint." 165 A trial judge who responded to a $\mathrm{Na}$ -

${ }^{156}$ D'Amato, Harmful Speech and the Culture of Indeterminacy, 32 WM. \& MARY L. REv. 329, 332 (1991).

${ }^{157}$ Perlin, supra note 151, at 59-61; see generally, Perlin \& Dorfman, supra note 6.

${ }^{158}$ Perlin, supra note 151, at 61-69.

${ }^{159}$ See Perlin, supra note 152 , at $400-04$.

${ }^{160}$ See e.g., Corn v. Zant, 708 F. 2d 549, 569 (11th Cir. 1983), reh. den., 714 F. 2d 159 (11th Cir. 1983), cert.den., 467 U.S. 1220 (1984) (defendant referred to as a "lunatic"); Sinclair v. Wainwright, 814 F. 2d 1516, 1522 (11th Cir., 1987), quoting Shuler v. Wainwright, 491 F. 2d 213 (5th Cir. 1974) (using "lunatic"); Brown v. People, 8 ill. 2d 540, 134 N.E. 2d 760, 762 (1956) (judge asked defendant, "You are not crazy at this time, are you?"); Pyle v. Boles, 250 F. Supp. 285, 289 (N.D. W. Va. 1966) (trial judge accused habeas petitioner of "being crazy"); but cf. State v. Penner, 772 P. 2d 819 (Kan. 1989) (unpublished disposition), at *3 (witnesses admonished not to refer to defendant as "crazy" or "nuts").

${ }^{161}$ See e.g., Commonwealth v. Musolino, 320 Pa. Super. 425, 467 A. 2d 605 (1983) (reversible error for trial judge to refer to expert witnesses as "headshrinkers"); compane State v. Pency, 146 Vt. 475, 507 A. $2 d$ 955, 956 (1986), app'l after nemand,-Vt.-, 595 A. 2 d 248 (1990), cert. den., 112 S. Ct. 344 (1991) (conviction reversed where prosecutor, in closing argument, referred to expert testimony as "psychobabble").

${ }^{162}$ People v. LaLone, 432 Mich. 103, 437 N.W. 2d 611, 613 (1989), reh. den. (1989).

${ }^{163}$ In re Melton, 597 A. 2d 892, 898 (D.C. 1991).

${ }^{164}$ See e.g., J. Monahan, The Clinical Prediction of Violent Behavior (1981); Monahan, Risk Assessment of Violence Among the Mentally Disordered: Generating Useful Knowledge, 11 INTL J. L. \& Psychiatry 249 (1989); Monahan, Mental Disorder and Violent Behavior: Perceptions and Evidence, 48 AM. Psycholooist 511 (1992); Slobogin, Dangerousness and Expertise, 133 U. PA. L. Rev, 97 (1984).

${ }^{165}$ Perlin, supra note 152, at 396; see also, e.g., Balkin, The Rhetoric of Responsibility, 76 VA. L. REV. 197, 238 (1990) (Hinckley prosecutor suggested to jurors, "if Hinckley had emotional problems, they were largely his own fault"); State v. Duckworth, 496 So. 2d 624, 635 (La. App. 1986) (juror who felt defendant would be responsible for actions as long as he "wanted to do them" not excused for cause) (no error). 
tional Center for State Courts survey indicated that, in his mind, defendants who were IST could have understood and communicated with counsel and the court "if they [had] only wanted."

Pretextuality. ${ }^{167}$ The entire relationship between the legal proces and mentally disabled litigants is often pretextual. ${ }^{168}$ This pretextuality is poisonous; it infects all players, breeds cynicism and disrespect for the law, demeans participants, and reinforces shoddy lawyering, blasé judging, and, at times, perjurious and/or corrupt testifying. The reality is well known to frequent consumers of judicial services in this area: to mental health advocates and other public defender/legal aid/legal service lawyers assigned to represent patients and mentally disabled criminal defendants, to prosecutors and state attorneys assigned to represent hospitals, to judges who regularly hear such cases, to expert and lay witnesses, and, most importantly, to the mentally disabled person involved in the litigation in question.

The Connection to Right to Refuse Treatment Law. The seemingly incoherent splits in right to refuse decision making can thus be explained by consideration of these jurisprudential constructs. Judges that employ heuristic devices, make sanist assumptions, and employ pretextual thinking decide cases that ignore social science data, privilege myths, and misstate established legal doctrine. Others, contrarily, read social science data carefully, avoid sanist thought processes and reject pretextual decision making.

The split between the panel and the en banc Fourth Circuit in United States v. Charters ${ }^{169}$ or the differences between the majority and the dissent in Riggins $v$. Nevada ${ }^{170}$ perfectly mirror this dichotomy. The Charters $I$ court carefully analyzed the available social science data as to the prevalence and severity of

\footnotetext{
${ }^{166} \mathrm{~K}$. Gould, I. Keilitz \& J. R. Martin, "Criminal Defendants with Trial Disabilities: The Theory and Practice of Competency Assistance" (unpublished manuscript), at 68; see also, Lamb, Deinstitutionalization and the Homeless Mentally III, 35 HhOSP. \& COMmuN. Psychiatry 899, 943 (1984) (society tends to "morally disapprove of [mentally disabled] persons who 'give in' to their dependency needs"). Compare Matter of Commitment of Tarpley, 581 N.E. 2d 1251 (Ind. 1991), reh. den. (1992) (error to hold defendant in contempt of court for failing to take medication as required by outpatient commitment).

${ }^{167}$ The material infra accompanying note 168 is generally adapted from Perlin, supra note 49, manuscript at $10-11$.

${ }^{168}$ By "pretextual," I mean that courts accept (either implicitly or explicitly) testimonial dishonesty and engage similarly in dishonest (frequently meretricious) decision making, see Perlin, Morality and Pretextuality, Psychiatry and Law: Of "Ordinary Common Sense," Heuristic Reasoning, and Cognitive Dissonance, 19 Bull. AM. ACAD. Psychiatry \& L. 131, 133 (1991), specifically where witnesses, especially expert witnesses, show a "high propensity to purposely distort their testimony in order to achieve desired ends," Sevilla, The Exclusionary Rule and Police Perjury, 11 SAN Diego L. Rev. 839, 840 (1974). Compare Butterfoss, Solving the Pretext Puzzle: The Importance of Ulterior Motives and Fabrications in the Supreme Court's Fourth Amendment Pretext Doctrine, 79 KY. L. J. 1 n. 1 (1990-91) (defining "pretexts" to include situations where "the government offers a justification for activity that, if the motivation of the [police] officer is not considered, would be a legally sufficient justification for the activity" as well as those activities for which the proffered justification is "legally insufficient").
}

${ }^{169} 829$ F. 2d 479 (4th Cir. 1987) (Charters I), on rehearing, 863 F. 2d 302 (4th Cir. 1988) (en banc) (Charters II), cert. den., 110 S. Ct. 1317 (1990); see generally, Perlin, supra note 10.

${ }^{170} 112$ U.S. 1810 (1992). 
side effects. ${ }^{171}$ The Charters 11 court, on the other hand, rejected as incredulous the possibility that a court could make a meaningful distinction between competency to stand trial and competency to engage in medication decision making:

[Such a distinction] must certainly be of such subtlety and complexity as to tax perception by the most skilled medical or psychiatric professionals ... To suppose that it is a distinction that can be fairly discerned and applied even by the most skilled judge on the basis of an adversarial fact-finding proceeding taxes credulity. ${ }^{172}$

The Charters II court was correct in its observation that "while there is universal agreement in the professional discipline that side effects always exist as a risk, there is wide disagreement within those disciplines as to the degree of their severity." ${ }^{\prime 173}$ While this is certainly true, this does not excuse the court from refusing to critically analyze the scientific research in coming to its ultimate decision. ${ }^{174}$

In the course of its decision, the Charters $I I$ court thus revealed its "apprehensiveness about dealing with underlying social, psychodynamic, and political issues that form the overt and hidden agendas in any right to refuse case."175 The court's decision also incorporated a broad array of heuristic devices in a way that led to the trivialization and misuse of the social science data before it. ${ }^{176}$ Through the employment of these devises, it:

. . . abdicated its responsibilities to read, harmonize, distinguish, and analyze social science data on the issues before it. It not only inadequately addressed the issue of side effects, but it also failed to adequately address issues concerning competency determinations, the therapeutic value of decision making, the empirical results of an announcement of a right to refuse treatment, and the courts' role in such processes. ${ }^{177}$

This trivialization of social science serves additional instrumental ends. It allows courts to more comfortably seek refuge in expressing commonsense "morality," to employ heuristic devices in a wide variety of cases in

${ }^{171}$ Charters, 829 F. 2d at 489 n. 2.

${ }^{17}$ Charters, 863 F. 2d at 120.

${ }^{173}$ Id. at 311.

${ }^{174}$ See Perlin, supra note 10, at 990-92; compare Monahan \& Walker, Judicial Use of Social Science Research, 15 LAW \& HUM. BEHAV. 571, 582-83 (1991) (setting out steps to be used by courts in analyzing social science evidence). As Professors Monahan and Walker observed in a different context on the question of judicial self-professed scientific illiteracy, "Anyone who can comprehend the Federal Tort Claims Act can learn what standard deviation and statistical significance mean." Monahan \& Walker, Social Authority: Obtaining, Evaluating, and Establishing Social Science in Law, 134 U. PA. L. Rev. 477, 511 n. 119 (1986).

${ }^{175}$ Perlin, supra note 10 , at 966.

${ }^{176}$ Perlin \& Dorfman, supra note 6, manuscript at 46.

${ }^{177}$ Perlin, supra note 10, at 999. 
"uncomfortable" areas of the law, and to use sanist behavior in deciding such cases. ${ }^{178}$

The Supreme Court's turnaround between Washington v. Harper and Riggins appears puzzling, and the two opinions seem virtually irreconcilable if they are both read as "right to refuse treatment cases." However, if Harper is seen as a prison security case, and Riggins as a fair trial case, then the rationales for the differences become clearer. Because the court, for a variety of normative and instrumental reasons, needed to reiterate strong prison security values, it decided Harper pretextually. ${ }^{179}$ Since this issue was absent from Riggins (who had not yet been convicted at the time of the employment of forced medications), the majority did not need to resort to such pretexts in its decision.

Even here, though, Justice Thomas's dissent reflects both sanism and pretextuality. His opinion raises grave questions for defense counsel: had his position prevailed, would defense lawyers have felt as if they were "assuming a risk" in ever seeking pretrial medical help for defendants awaiting trial? ${ }^{180}$ His analogizing psychiatric drug side effects to penicillin or aspirin may be disingenuous or it may be cynical. What is clear is that nowhere in the lengthy corpus of right to refuse litigation is this position ever seriously raised. ${ }^{181}$

The same methodology can perhaps be used to explain the lack of judicial attention that has been paid to such questions as the application of the right to refuse treatment to individuals found permanently incompetent to stand trial, awaiting trial in jails, or institutionalized following insanity acquittals, to other potentially invasive treatments beyond antipsychotic drugs (such as electroshock therapy or aversive conditioning, or to community or private facility settings. But here the blame can probably be more realistically placed on counsel than on the judiciary.

Lawyers representing mentally disabled individuals must familiarize themselves with information about the right to refuse treatment, both as to the law and as to the pharmacology. ${ }^{182}$ The track record of lawyers representing the

${ }^{178}$ The Charters II opinion

... reflects inappropriate heuristic thinking in a variety of contexts. It uses such distorting devices as availability, typification, the myth of particularistic proofs, and the "vividness effect"... The opinion's attempts to simplify one of the most complex problems facing decision makers, assessing mentally disabled individuals' capacity to retain some autonomous decision making power, further reflects the pernicious effect of the heuristic of attribution theory.

Perlin, supra note 10, at 986-87 (footnotes omitted).

${ }^{179}$ See 2 M. L. PERLIN, supra note 3, 85.64A, at 69-72 (Pocket part), discussing Justice Stevens' opinion critiquing the majority's read of the factual record in Harper.

${ }^{180}$ Riggins, 112 S. Ct. at 1823-24 (Thomas, J., dissenting), discussed in Perlin \& Dorfman, supra note 6, manuscript at 40-41.

${ }^{121}$ See Perlin \& Dorfman, supra note 6, manuscript at 41-42, and see id. at 42 n. 117, discussing Matter of Salisbury, 138 Misc. 2d 361, 524 N.Y.S, 2d 352, 354 (Sup. Ct. 1988) (no right to refuse antibiotics), the only case in which a similar issue is raised.

${ }^{10}$ See generally, Perlin \& Dorfman, supra note 6, manuscript at 60-61. 
mentally disabled has ranged from indifferent to wretched; ${ }^{183}$ in one famous survey, lawyers were so bad that a patient had a better chance of being released at a commitment hearing if he had appeared pro se. ${ }^{184}$ Further, simply educating lawyers about psychiatric technique and psychological nomenclature does not materially improve lawyers' performance where underlying attitudes are not changed. ${ }^{185}$ If counsel is to become even minimally competent in this area, it is critical that the underlying issues here be confronted. ${ }^{186}$ This is underscored by judges' lack of basic knowledge about mental disability law; in one astonishing case, a Louisiana civil commitment order was reversed where the trial court did not even know of the existence of a state-mandated mental health advocacy service. ${ }^{187}$

If lawyers continue to abdicate their advocacy role, it is not surprising that so many areas of application of the right to refuse treatment remain judicially unexplored.

\section{Therapeutic Jurisprudence ${ }^{18 B}$}

"Therapeutic jurisprudence" studies the role of the law as a therapeutic agent. ${ }^{189}$ This perspective recognizes that substantive rules, legal procedures,

\footnotetext{
${ }^{183}$ See Perlin, Fatal Assumption: A Critical Evaluation of the Role of Counsel in Mental Dlsability Cases, 16 LAw \& Hum. Behav. 39, $43-45$ (1992); see also, e.g., Schwartz, Damage Actions as a Strategy for Enhancing the Quality of Care of Persons With Mental Disabilities, 17 N.X.U. Rev. L. \& Soc. Chanae 651,662 (1989-90) (describing "wholesale lack of legal advocacy" available to patients in public mental institutions).

${ }^{14}$ Andalman \& Chambers, Effective Counsel for Persons Facing Civll Commitment: A Survey, a Polemic, and a Proposal, 45 Miss. L.J. 43, 72 (1974). One half of the lawyers assigned to represent individuals in civil commitment cases in Dallas were unaware of the existence of either of the two treatises written specifically about Texas's mental health law. Shuman \& Hawkins, The Use of Alternatives to Institutionalization of the Mentally III, 33 Sw. L.J. 1181, 1193-94 (1980) (attorneys received \$25 per case); accord, Perlin, supra note 183, at 50 n. 66 (Virginia attorneys received \$2S per case as of 1984).

${ }^{185}$ Poythress, Psychiotric Expertise in Civil Commitment: Training Attorneys to Cope With Expert Testimony, 2 LAw \& HuM. BeHAv. 1, 15 (1978). There is similar evidence in other areas of the law that knowledge alone is an insufficient impetus for attitudinal change. See e.g., Bohm, Clark \& Aveni, Knowledge and Death Penalty Opinion: $A$ Test of the Marshall Hypothesis, 28 J. RES. CRIME \& DeLIN7DQ. 360 (1991).

${ }^{18}$ For a rare judicial acknowledgement of the impact of lawyer incompetency in another area where inadequate counsel leads to morally intolerable results, see Engberg v. Meyer, 820 P. 2d 70, 104 (Wyo. 1991) (Urbigkit, C.J., dissenting in part \& concurring in part) ("We . . . let 'chiropractors' with law degrees perform the equivalent of brain surgery in capital cases, and, predictably, the 'patient' often dies. This is intolerable.").

${ }^{187}$ In re C.P.K., 516 So. 2d 1323, 1325 (La. App. 19878).

${ }^{188}$ The material infra accompanying notes $189-92$ is generally adapted from Perlin \& Dorfman, supra note 6, manuscript at 56-57.

${ }^{189}$ See Therapeutic JuRisprudence: The Law as a Therapeutic AGent, supra note 20; essays in THERAPEUTIC JURISPRUDENCE (D. Wexler \& B. Winick eds. 1991); Wexler, Therapeutic Jurisprudence and Changing Conceptions of Legal Scholarship, 11 BeHAv. SCI. \& L.-(1992) (in print); Wexler, Putting Mental Health in Mental Health Law, 16 LAw \& HuM. BeHAv. 27 (1992) (Wexler, Putting Mental Health); Wexler \& Winick, Therapeutic Jurisprudence and Criminal Justice Mental Health Issues, 16 MENT. \& PHYS. Dis. L. RPTR. 225 (1992); Wexler \& Winick, Therapeutic Jurisprudence as a New Approach to Mental Health Law Policy Analysis and Research, 45 U. MiAMI L. Rev. 979 (1991) (Wexler \& Winick, New Approach).
} 
and lawyers' roles may have either therapeutic or antitherapeutic consequences, and questions whether such rules, procedures, and roles can or should be reshaped so as to enhance their therapeutic potential, while not subordinating due process principles. ${ }^{190}$

While an impressive body of literature has been produced, ${ }^{191}$ there has not yet been a systematic investigation into the reasons why some courts decide cases "therapeutically" and others "antitherapeutically." My preliminary conclusion is that sanism is such a dominant psychological force that it (a) distorts "rational" decision making, (b) encourages (albeit on at least a partially unconscious level) pretextuality, and (c) prevents decision makers from intelligently and coherently focusing on questions that are meaningful to therapeutic jurisprudential inquiries. ${ }^{192}$

In Right to Refuse Treatment Cases. ${ }^{193}$ It should be intuitively self-evident that the area of the right to refuse treatment is as fertile a field as one can imagine for the application of these insights. There is truly a broad array of topics for scholars to examine: the "real world" implications of decisions expanding (or contracting) the substantive right to refuse, and the scope of procedural due process protections available to right to refuse invokers; ${ }^{194}$ the impact of what Stanley Brodsky has called "litigaphobia"195 (and what may simply be a rarified form of passive-aggressive behavior) ${ }^{196}$ in mental health professionals' responses to court orders mandating the right to refuse $;^{197}$ the postinstitutional impact of refusal; ${ }^{198}$ the implications of what Thomas Gutheil and his colleagues have called "critogenesis" (meaning the "inherent risks of legal intervention in medical decisionmaking"199 in right to refuse litigation);

\footnotetext{
${ }^{150}$ Wexler, Health Care Compliance Principles and the Insanity Acquittee Conditional Release Process, 27 CrIM. L. Bull. 18, 19 n. 5 (1991); see generally, Wexler, Putting Mental Health, supra note 189.

${ }^{191}$ See Wexler \& Winick, New Approach, supra note 189, at 981 n. 9.

${ }^{192}$ See M. Perlin, supra note 56 (suggesting that influence of sanism must be considered in therapeutic jurisprudence investigations).

${ }^{193}$ Much of the text infra accompanying notes 194-202 is generally adapted from Perlin, supra note 9, at 54-55.

${ }^{194}$ See 2 M. L. PerLiN, supra note 3, at 885.47-5.51; Perlin, supra note 49, at 104 n. 245.

${ }^{195}$ See Brodsky, Fear of Litigation in Mental Health Professionals, 15 CRIM. Just. \& BeHAV. 492, 497 (1988).

${ }^{106}$ Zito, Haimotitz, Wanderling \& Mehta, supra note 50.

${ }^{19}$ I discuss Brodsky's and Zito's insights in this context in Perlin, supra note 10, at 989 n. 211, and id. at 984-85.

${ }^{198}$ Compare Rennie v. Klein, 476 F. Supp. 1294, 1299-1300 (D.N.J. 1979) (antipsychotic drugs also serve to "inhibit a patient's ability to learn social skills needed to fully recover from psychosis"), to In re Melton, 565 A. 2d 635, 649 (D.C. 1989) (Schwelb, J., dissenting), vacated and rehearing granted, 581 A. 2 d 788 (1990), superceded on rehearing, 597 A. $2 \mathrm{~d} 892$ (D.C. 1991):

I am constrained to wonder how many of the homeless persons who live wretched and squalid lives ... . are there because they have "won," through litigation or the threat thereof, ... the "liberty" not to be required to take medication essential to their mental health.

${ }^{199}$ See Gutheil, Burstzajn, Kaplan \& Brodsky, Participation in Competency Assessment and Treatment Decisions: The Role of the Psychiatrist-Attorney Team, 11 MENT. \& PHYs. DIs. L. RPTR. 446, 449 (1987). I discuss this criticism in Perlin, supra note 32, at 88-89 n. 151.
} 
the extent to which courts are even willing to consider the underlying social science data. ${ }^{200}$

We have not even skimmed the surface of this important investigation; if scholars and researchers turn their attention to it seriously, it adds one more important set of factors "into the mix" that must be considered in making predictions about future judicial behavior. ${ }^{201}$

\section{Conclusion}

In order to understand right to refuse treatment law, we must decode it. It is not enough to simply discuss the right as a "turf battle" between patients" rights lawyers and clinicians or as a trompe d'oeil effect (that reflects either a series of fixed constitutional principles or of treatment decisions). As I have sought to demonstrate in this article, the right remains the most volatile area of mental disability law but it is one that can be contextualized if the jurisprudential and cognitive constructs just discussed are always kept in mind.

The general conservative trend of the federal courts has created a "shadow land" of right to refuse litigation in state courts, a universe that will most likely continue to grow both quantitatively and qualitatively, but that will be recalibrated as a result of the Supreme Court's recent Riggins decision. The split in the courts reflects radically different visions of the role of the judiciary in overseeing institutional conditions and care. While there is a substantial body of right to refuse law dealing with certain discrete populations, many other important subclasses have been the subject of negligible litigation; whether or not these become "growth areas" in the near and distant future depends largely on the extent to which counsel begins to serve a true representational role in this area. It is necessary that the precise status of the patient e.g., jail detainee; prisoner; insanity acquittee; Jacksonized permanently incompetent-be "unpacked" so as to "decode" the operative, controlling legal principles. Finally, it is not enough to simply look at the issue as if it reflects only questions of "patients" rights" or "treaters' autonomy." It is also necessary to weigh and consider cognitive psychology insights, constructs such as "sanism" and "pretextuality," and therapeutic jurisprudence principles into our data base to help understand why courts do what they do and what the ultimate impact of their actions will be.

If all of this is done, it is possible that some harmony might be brought to this area of litigation, and that the dilemma at the heart of the controversy "preserving patient dignity while maintaining allegiance to treatment needs" ${ }^{1202}$ - might yet be resolved.

\footnotetext{
${ }^{200}$ See generally, Perlin \& Dorfman, supra note 6.

${ }^{201}$ I consider Riggins in this context in M. Perlin, supra note 56, and Perlin, supra note 21.

${ }^{202}$ Roth, supra note 56 , at 161 .
} 